\title{
The Role of IT in Innovation at the Organizational Level - A Literature Review
}

\author{
Stanislav Mamonov \\ Montclair State University \\ stanislav.mamonov@montclair.edu
}

\author{
Richard Peterson \\ Montclair State University \\ richard.peterson@montclair.edu
}

\begin{abstract}
Information technology (IT) is broadly recognized as an important element that supports innovation, however there has been relatively little integration of research in Information Systems on this topic. In this literature review, we examine and synthesize studies on the role of IT in innovation at the organizational level of analysis published in the past ten years in the leading Information Systems journals. We find that while much of the research has generally demonstrated positive effects of IT investments on innovation, IT can also be a cause of hyperturbulence in specific industries, and many factors can moderate the returns realized from IT investments. We also note that extant research is grounded in a relatively narrow theoretical foundation and we discuss the opportunities for developing the theoretical base on the role of IT in innovation.
\end{abstract}

\section{Introduction}

Innovation, i.e. development of new products and services as well as entry into new markets, has been long recognized as an essential element of business strategy [80]. Information technology plays an important role in supporting innovation within organizations [51], as well as being a component of innovative product [56] and service offerings [48], and a conduit into new markets [56]. While there is a growing body of literature examining the role of technology in supporting and enabling innovation across different contexts, there has been little theoretical integration within this stream of literature [33].

We take a step toward theoretical integration of the emergent insights here by conducting a literature review of innovation-related research at the organizational level of analysis. This study is a part of a broader project that examines interdisciplinary research on the effects of IT on innovation across different levels of analysis [49]. Here we present the results of a systematic review [80] that focuses on the top Information Systems journals as sources of studies with significant theoretical impact.
The following research questions guide our literature review. RQ1: Which theoretical perspectives are being used to examine the role of IT in innovation at the organizational level of analysis? RQ2: What are the focal IT and innovation-related constructs in innovation research at the organizational level of analysis in Information Systems? RQ3: What is known about the role of IT in supporting innovation at the organizational level?

We find that much of the published research on innovation is narrowly theoretically grounded in either the resource-based view (RBV) $[8,10]$ or the dynamic capabilities theories [27]. Much of the published work examines the effects of IT investments on high-level outcomes of innovation efforts reflected in the financial performance of a firm (firm survival, sales, stock price). Studies generally document a positive association between IT investments and firm performance [7, 44], however more recent studies suggest diminishing returns for smaller firms [39] and non-technical sectors of the economy [65]. We also find two native IS theories in our sample. Ning and Tanriverdi [52] highlight the dual role of IT as a source of disruptions in the market and as an essential component of a competitive response to market disruptions. Lusch and Nambisan [28] offer a service-dominant logic perspective on the critical role of IT in innovation that emphasizes resource liquification, i.e. decoupling of information from its physical form, as the foundation for service innovations.

The remainder of the manuscript is structured as follows. In Section 2, we provide a brief overview of innovation-related research that guides the framing of our analysis. In Section 3, we discuss the methodology underlying the selection of the studies included in this review, in Section 4, we present the analysis of the selected literature and, in Section 5, we discuss the implication of the results.

\section{Theoretical background}

Innovation has been the focus of research across disciplines [12, 33, 58, 63] and a full review of prior work is beyond the scope of the current manuscript. 
Here we summarize two themes in the organizational innovation research that are relevant to our work. First, we outline a typology that distinguishes different types of innovations. Different innovation types present different challenges and may benefit from different types of IT. Second, we summarize the key factors that have been shown to have a significant effect on innovation at the organizational level in management research. Understanding the organizational factors that impact innovation can help in understanding the interplay between the IT and these organizational factors.

\subsection{Innovation and innovation types}

To understand how information technology can affect innovation at the organizational level, we need an operational definition of innovation. While many competing definitions of innovation have been proposed [22], we draw on the definition recently developed by Anderson et al. [4] which emphasizes that innovation as a concept describes both the process and the outcomes of "attempts to develop and introduce new ways of doing things." This conceptualization of innovation covers a very broad range of activities and outcomes. With the goal of identifying more coherent subgroups of innovation-related studies, we further draw on several established typologies of innovation that distinguish 1) internally versus externally focused 2) incremental versus radical, and 3) closed versus open innovation [18, 45, 53].

Internally focused innovation aims at developing new ways of doing things within the organization, whereas externally focused innovation aims at developing new product or service offerings for the markets [24]. The distinction between incremental versus radical innovation is determined in relation to the starting state [26, 29]. Radical innovations are often discussed as disruptions within industries because they introduce fundamentally new products or services and reshape the markets [29], whereas incremental innovations seek to add features or functionality to existing products or services. Internally focused radical innovations reshape value creation within the organizations, commonly offering substantial cost savings and scale benefits to the innovating organizations [38].

Open innovation is distinguished from closed innovation by the participation of external agents, e.g. partners and customers, in the innovation process [18]. Open innovation poses novel challenges in terms of structure and governance related to the external agent participation in the innovation process [31, 34].

Prior analysis of innovation-related studies in management noted that innovation is affected by firmlevel factors as well as the context, e.g. the level of competition in the industry, within which the innovation is being developed [4]. Different types of innovation contexts present different environmental considerations. By focusing on the specific innovation context subtypes, we aim to synthesize the insights from extant research on the role of IT within the specific contexts and identify opportunities for further research.

\subsection{Organizational factors that affect innovation}

Innovation management has been a very active area of research in management and several authors have offered a synthesis of extant management research [1, 2, $3,50,60]$. Crossan and Apaydin [22] suggest that the key factors that affect organizational innovation can be grouped into three themes: leadership, managerial levers, and business processes.

Leadership encompasses the CEO as well as senior executives within a company and the board of directors. For example, prior research has shown that the CEO's tolerance for change and the board's professional diversity are significantly correlated with organizational innovation [23, 35].

Managerial levers encompass a broad spectrum of structures and activities that include a firm's strategy, line-of-business systems, allocation of resources, organizational culture and organizational learning support mechanisms [22]. Among other results, research in this domain has shown that the alignment of innovation initiatives with the firm's overall strategy [74], establishment of an organizational climate that is supportive of experimentation [5], and investment in employee development [21] have positive effects on the innovation output of a firm.

Business process related factors cover a wide range of institutionalized processes that enable and support innovation-related activities. These include formalization of the ideation process, innovation portfolio management strategies, systems and tools that support communication and collaboration as well as market entry and development strategies [22]. Prior research in this areas has shown that formalized market opportunity sensing [19], implementation of ideation platforms [13], and systematic approach to market analysis [78] can positively influence organizational innovation.

\section{Methodology}

In developing this literature review, we follow the guidelines in [80]. The present study is a part of a larger effort focusing on a comprehensive examination of the role IT in enabling and supporting innovation. Google Scholar returns over 3.5 million results for the "innovation and technology" search phrase. Given the 
overwhelming volume of research in this domain and following the recommendations in [80], we focused this initial review on the research published in the top four Information Systems journals: Management Information Systems Quarterly (MISQ), Information Systems Research (ISR), Journal of Management Information Systems (JMIS), and Journal of the Association for Information Systems (JAIS). Top journals were selected because they emphasize novel theoretical contributions as a key consideration for publication [69] and therefore they serve as a good lens for identifying the core theoretical discourses in the published literature.

To select the studies for the analysis we searched the respective journals for articles containing the word "innovation" in either the title, the abstract or the list of keywords. In aggregate, we retrieved 495 manuscripts across the four journals. Table 1 summarizes the manuscript count retrieved from each journal.

Table 1. Distribution of innovation-related studies in the senior scholars' basket of journals

\begin{tabular}{|l|r|r|}
\hline & Search results & \% contribution \\
\hline MISQ & 84 & $17.0 \%$ \\
\hline$I S R$ & 282 & $57.0 \%$ \\
\hline$J M I S$ & 62 & $12.5 \%$ \\
\hline$J A I S$ & 67 & $13.5 \%$ \\
\hline
\end{tabular}

In the next step, because our focus is on the role of information technology in innovation, we examined the abstracts and, where necessary, full manuscripts to determine whether IT-enabled innovation was a substantive part of each study. We excluded review articles and editorials from our analysis. The remaining set consisted of 301 studies. Next, we examined the studies to determine the level of analysis in each. For this literature review, we selected only the studies at the organizational level of analysis. Due to the length constraints of this manuscript, we excluded studies focusing on value co-creation and open innovation from the present analysis. This left us with 35 empirical and theoretical studies that focus on the role of information technology in innovation at this level of analysis.

\section{Analysis}

\subsection{Theoretical perspectives and focal innovation-related constructs}

In the first step of our analysis, we examine the theoretical perspectives and focal IT and innovation- related constructs. We find that studies focusing on innovation as an outcome generally follow a very different blueprint when compared to studies focusing on innovation as a process. Whereas outcome focused studies tend to present empirical evaluation of elaborations on the established theories, much of the process focused literature attempts to develop novel perspectives on innovation through case studies.

The majority of the innovation outcome focused studies are based in either the resource-based view (RBV) [9] or the dynamic capabilities literature [73]. We also find elaborations on the RBV and dynamic capabilities in the form of knowledge-based view of the firm [75] and organizational learning theory [82], as well as a study leveraging agency theory to understand how contracting affects a firm's ability to capture value from innovations [70]. Consistent with the dominant theoretical frames, we find that the focal IT-related constructs examine investment in IT assets/resources [20, 25, 65] or IT-enabled capabilities, e.g. IT-enabled absorptive capacity [42] and big data analytics capability [16].

Focusing on the innovation-related dependent variables in our sample, we find that many studies focus on firm survival and firm overall performance. Firm performance is measured as sales, firm value, and/or profitability. We also find studies focusing on ideation within an organization [61], new product development [54], product/service introductions [82], and patents [44]. Table 2 summarizes the theoretical perspectives, IT and innovation related focal constructs as well as the key insights from the studies focusing on the innovation related outcomes.

Process-focused innovation-related research in our sample, without exception, leverages case studies to evaluate extant theories as well as to develop novel theoretical ideas. For example, a case study of rural telehealth initiative in India suggests that neither path dependency nor contingency theories fully capture the path of the initiative [67]. The authors suggest that a "path constitution" perspective that recognizes some path-related dependencies, while also acknowledging the generative nature of the innovation process is a better theoretical frame for understanding how innovations evolve. Process-oriented studies note that more established firms often take a measured approach to implementing innovations within organizations [37], whereas startups emphasize rapid data-driven innovation as the core mode of operation [40]. Table 3 summarizes the key insights that emerged from the process-focused research in our sample.

\section{Table 2. A summary of theories, IT and innovation-related constructs in outcomes focused research}




\begin{tabular}{|c|c|c|c|}
\hline $\begin{array}{l}\text { Reference / } \\
\text { Theoretical } \\
\text { perspective }\end{array}$ & $\begin{array}{l}\text { IT-related } \\
\text { construct(s) }\end{array}$ & $\begin{array}{l}\text { Focal (innovation } \\
\text { related) } \\
\text { construct(s) }\end{array}$ & Key insights \\
\hline $\begin{array}{l}{[25]} \\
\mathrm{RBV}\end{array}$ & IT assets & $\begin{array}{l}\text { Profitability } \\
\text { Risk }\end{array}$ & $\begin{array}{l}\text { An analysis of Fortune } 1000 \text { firms in the period between } \\
\text { 1987-1994 shows that IT investment is associated with } \\
\text { increased risk. The effects are stronger for service firms. }\end{array}$ \\
\hline $\begin{array}{l}{[20]} \\
\text { RBV }\end{array}$ & IT investment & $\begin{array}{l}\text { Labor investment } \\
\text { Financial capital } \\
\text { investment }\end{array}$ & $\begin{array}{l}\text { An analysis of } 800 \text { firms in the period between } 1987-1998 \\
\text { shows that IT investment is substitutive to labor, but it is } \\
\text { complementary to capital investment. }\end{array}$ \\
\hline $\begin{array}{l}\text { [43] } \\
\text { Absorptive } \\
\text { capacity }\end{array}$ & $\begin{array}{l}\text { IT-enabled } \\
\text { absorptive capacity }\end{array}$ & $\begin{array}{l}\text { Innovations } \\
\text { (patents and } \\
\text { product/service } \\
\text { introductions) }\end{array}$ & $\begin{array}{l}\text { There is relatively weak relationship between potential and } \\
\text { realized IT-enabled absorptive capacity. Realized absorptive } \\
\text { capacity is strongly related to ideated innovation. IT-enabled } \\
\text { social integration capacity interacts with ideated innovation } \\
\text { to produce commercialized innovation. }\end{array}$ \\
\hline $\begin{array}{l}54] \\
\text { Dynamic } \\
\text { capabilities }\end{array}$ & $\begin{array}{l}\text { IT-enabled } \\
\text { improvisational } \\
\text { capabilities }\end{array}$ & $\begin{array}{l}\text { New product } \\
\text { development }\end{array}$ & $\begin{array}{l}\text { The authors propose that IT contributes to the } \\
\text { improvisational capabilities of a firm and distinguish } \\
\text { improvisational capabilities from dynamic capabilities. The } \\
\text { study shows that while dynamic capabilities play a key role } \\
\text { in moderately turbulent environments, improvisational } \\
\text { capabilities dominated in highly turbulent environments. }\end{array}$ \\
\hline $\begin{array}{l}{[77]} \\
\text { Theory } \\
\text { development }\end{array}$ & $\begin{array}{l}\text { IT is conceptualized } \\
\text { as an enabling } \\
\text { mechanism in the } \\
\text { evaluation, planning } \\
\text { and execution of } \\
\text { competitive actions. }\end{array}$ & $\begin{array}{l}\text { Innovation is } \\
\text { implicitly } \\
\text { embedded in the } \\
\text { competitive action } \\
\text { plan. }\end{array}$ & $\begin{array}{l}\text { Practitioners recognize the embedded role of IS within the } \\
\text { competitive actions. Managers see IT as a resource that } \\
\text { provides opportunities for competitive action. IT supports } \\
\text { information flow within the organization and this is critical } \\
\text { in the conception of the strategic action plan. IT also } \\
\text { supports evaluation of competitive action options and the } \\
\text { execution of the chosen plan. }\end{array}$ \\
\hline $\begin{array}{l}{[46]} \\
\text { Dynamic } \\
\text { capabilities }\end{array}$ & $\begin{array}{l}\text { Operational } \\
\text { capabilities }\end{array}$ & Firm survival & $\begin{array}{l}\text { IT-enabled operational capability has the largest effect on } \\
\text { firm survival across } 5827 \text { software firms between 1995- } \\
2007 \text {. }\end{array}$ \\
\hline $\begin{array}{l}\text { [79] } \\
\text { RBV }\end{array}$ & IT investment & Firm performance & $\begin{array}{l}\text { Firms investing in the latest technology have higher } \\
\text { reputation and higher executive compensation. No effect is } \\
\text { found for IT investments on performance in the short term, } \\
\text { but there is an improvement in performance over the longer } \\
\text { term. }\end{array}$ \\
\hline $\begin{array}{l}{[70]} \\
\text { Agency theory }\end{array}$ & IT capabilities & Firm survival & $\begin{array}{l}\text { Economic modeling shows that contractual misalignment } \\
\text { with the underlying cost structure undermines business } \\
\text { sustainability. The cost of contractual adjustment is also a } \\
\text { factor in a firm's ability to align the contractual structure. }\end{array}$ \\
\hline $\begin{array}{l}{[44]} \\
\text { RBV }\end{array}$ & IT investment & $\begin{array}{l}\text { Sales } \\
\text { \# of patents }\end{array}$ & $\begin{array}{l}\text { An analysis of large manufacturing firms between } 1987- \\
1997 \text { shows that a } 10 \% \text { increase in IT spending is associated } \\
\text { with a } 1.7 \% \text { increase in sales. }\end{array}$ \\
\hline $\begin{array}{l}\text { [82] } \\
\text { Organizational } \\
\text { learning } \\
\text { theory }\end{array}$ & IT assets & $\begin{array}{l}\text { Innovation (new } \\
\text { product } \\
\text { introductions) }\end{array}$ & $\begin{array}{l}\text { Panel data analysis of } 341 \text { firms from } 2003-2005 \text { shows that } \\
\text { lower levels of industry dynamism, munificence, and } \\
\text { complexity IT assets are associated with greater efficiency. } \\
\text { Higher complexity (more competing firms) is associated } \\
\text { with more innovation. }\end{array}$ \\
\hline $\begin{array}{l}{[62]} \\
\text { Organizational } \\
\text { agility }\end{array}$ & IT investment & $\begin{array}{l}\text { Customer agility - } \\
\text { responsiveness to } \\
\text { customer-based } \\
\text { opportunities for } \\
\text { innovation. }\end{array}$ & $\begin{array}{l}\text { A survey of } 188 \text { marketing managers shows that IT } \\
\text { facilitates "knowledge creating" synergy that is derived from } \\
\text { the interaction between a firm's web-based customer } \\
\text { infrastructure and its analytical ability. IT also supports } \\
\text { "process enhancing" synergy that arises from the interaction } \\
\text { between a firm's coordination efforts and its level of IT } \\
\text { integration and enables the firm to respond to opportunities. }\end{array}$ \\
\hline $\begin{array}{l}{[65]} \\
\text { RBV }\end{array}$ & IT investment & $\begin{array}{l}\text { Stock returns } \\
\text { Stock volatility }\end{array}$ & $\begin{array}{l}\text { IT investment opportunities are diminished in some sectors } \\
\text { of the economy, e.g. logistics. }\end{array}$ \\
\hline $\begin{array}{l}{[72]} \\
\text { RBV }\end{array}$ & IT investment & Value added & $\begin{array}{l}\text { IT returns are substantially lower in midsize firms. IT returns } \\
\text { materialize more slowly in large firms. }\end{array}$ \\
\hline $\begin{array}{l}{[7]} \\
\text { RBV }\end{array}$ & IT investment & Firm value & $\begin{array}{l}\text { Investments in IT complement investments in R\&D to } \\
\text { deliver business value. }\end{array}$ \\
\hline
\end{tabular}




\begin{tabular}{|c|c|c|c|}
\hline $\begin{array}{l}{[32]} \\
\text { RBV }\end{array}$ & IT assets & $\begin{array}{l}\text { Return on IT } \\
\text { investment }\end{array}$ & $\begin{array}{l}\text { Innovation resource/posture misalignment diminishes returns } \\
\text { on IT investments. Innovation posture - the innovation stage: } \\
\text { comprehension, adaption, implementation, assimilation. IT } \\
\text { innovation resource - the stock of human and organizational } \\
\text { resources conducive to efficient and effective innovation } \\
\text { with IT. }\end{array}$ \\
\hline $\begin{array}{l}{[15]} \\
\text { Dynamic } \\
\text { capabilities }\end{array}$ & IT resources & $\begin{array}{l}\text { Perceptions of firm } \\
\text { innovation }\end{array}$ & $\begin{array}{l}\text { A survey-based study shows that organizational wisdom, } \\
\text { courage and temperance are associated with improvisational } \\
\text { capabilities. }\end{array}$ \\
\hline $\begin{array}{l}{[16]} \\
\text { Dynamic } \\
\text { capabilities }\end{array}$ & $\begin{array}{l}\text { Big data analytics } \\
\text { capability }\end{array}$ & Firm value & $\begin{array}{l}\text { Expected benefits, technology capability, organizational } \\
\text { readiness and competitive pressure affect big data analytics } \\
\text { use. Analytics use is positively associated with asset } \\
\text { productivity and business growth. }\end{array}$ \\
\hline $\begin{array}{l}{[61]} \\
\text { Dynamic } \\
\text { capabilities }\end{array}$ & $\begin{array}{l}\text { Routine IT use } \\
\text { Innovative IT use }\end{array}$ & $\begin{array}{l}\text { Volume and } \\
\text { diversity of ideas } \\
\text { for organizational } \\
\text { innovation. }\end{array}$ & $\begin{array}{l}\text { A survey of } 248 \text { managers reveals that routine IT use does } \\
\text { not affect ideas for organizational innovation. Innovative use } \\
\text { of IT is positively related to the volume and diversity of } \\
\text { ideas. Organizational autonomy and innovativeness are } \\
\text { positive moderators. }\end{array}$ \\
\hline $\begin{array}{l}{[6]} \\
\text { Dynamic } \\
\text { capabilities }\end{array}$ & $\begin{array}{l}\text { Collaborative } \\
\text { technology use }\end{array}$ & $\begin{array}{l}\text { IT-enabled } \\
\text { collaborative } \\
\text { capability }\end{array}$ & $\begin{array}{l}\text { Collaboration technology use has a positive effect on the } \\
\text { collaboration satisfaction. This effect is stronger for } \\
\text { employees involved in new product development. }\end{array}$ \\
\hline $\begin{array}{l}{[59]} \\
\text { RBV }\end{array}$ & IT investment & Firm value & $\begin{array}{l}\text { Panel data analysis of } 161 \text { firms in the period } 1991-2003 \\
\text { shows that IT investments can mitigate diminishing returns } \\
\text { from R\&D investments. The effect is stronger for more } \\
\text { complex R\&D sectors. }\end{array}$ \\
\hline $\begin{array}{l}{[75]} \\
\text { Knowledge- } \\
\text { based view }\end{array}$ & IT capabilities & Process innovation & $\begin{array}{l}\text { Panel data analysis of Swiss firms between } 2005-2011 \text { shows } \\
\text { that IT capabilities (data access and network connectivity) } \\
\text { interact with the number of external knowledge sources in } \\
\text { their effect on process innovation. }\end{array}$ \\
\hline $\begin{array}{l}{[52]} \\
\text { Theory } \\
\text { development }\end{array}$ & IT assets & $\begin{array}{l}\text { Hyperturbulence } \\
\text { response }\end{array}$ & $\begin{array}{l}\text { IT can be a cause of hyperturbulence by being a component } \\
\text { of disruptive innovations. IT can also alleviate a firm's } \\
\text { response to hyperturbulence in supporting absorptive } \\
\text { capacity. }\end{array}$ \\
\hline $\begin{array}{l}\text { [64] } \\
\text { Absorptive } \\
\text { capacity }\end{array}$ & $\begin{array}{l}\text { Information } \\
\text { processing and } \\
\text { analytical } \\
\text { capabilities }\end{array}$ & $\begin{array}{l}\text { Innovation } \\
\text { (patents) }\end{array}$ & $\begin{array}{l}\text { Analytical information processing capability interacts with } \\
\text { information-intensive customer evolvement and relational } \\
\text { information processing interacts with product-focused } \\
\text { customer involvement in producing positive effects on the } \\
\text { number of patents filed. }\end{array}$ \\
\hline $\begin{array}{l}{[30]} \\
\text { RBV }\end{array}$ & Big data assets & Firm productivity & $\begin{array}{l}\text { Big data asset ownership is associated with } 3-7 \text { percent } \\
\text { improvement in firm productivity. The effect is present for } \\
\text { IT-intensive and highly competitive industries. It is not } \\
\text { present for non IT-intensive less competitive markets. }\end{array}$ \\
\hline $\begin{array}{l}{[11]} \\
\text { RBV }\end{array}$ & IT outsourcing & Firm value & $\begin{array}{l}\text { Announcements related to outsourcing of mature IT services } \\
\text { have a positive near-term effect. The value of less mature IT } \\
\text { outsourcing decisions takes longer to be realized. }\end{array}$ \\
\hline $\begin{array}{l}{[36]} \\
\text { RBV }\end{array}$ & IT investment & Firm value & $\begin{array}{l}\text { Panel data analysis of } 294 \text { firms in the period } 1999-2008 \\
\text { shows that environmental turbulence increases the positive } \\
\text { interaction effect between IT and R\&D investments. }\end{array}$ \\
\hline $\begin{array}{l}{[68]} \\
\text { RBV }\end{array}$ & IT investments & Firm value & $\begin{array}{l}\text { IT investments benefit the firm when the firm has the } \\
\text { capacity to monetize the acquired technology. }\end{array}$ \\
\hline
\end{tabular}

Table 3. A summary of process-focused research

Ref $\quad$ Summary of insights

[37] The study of several IT projects within a Scandinavian airline suggests that projects progress through adoption, innovation and scaling stages. The adoption stage captures the initial introduction of a technology within organization, innovation is the effective use of novel technology within a unit, and scaling refers to organization-wide adoption of the technology.

[67] A case study of rural telehealth in India through the lens of innovation and path dependency theories suggests that neither path dependency nor contingency perspectives offer a good fit to the observed platform development. The authors suggest a "path constitution" perspective as an alternative view. 


\begin{tabular}{|l|l|}
\hline$[40]$ & $\begin{array}{l}\text { A case study of WeCash, a Chinese digital payment venture, suggests that data-driven operation, instant release and } \\
\text { swift transformation are the key generative mechanisms that underpin successful rapid scaling. }\end{array}$ \\
\hline$[41]$ & $\begin{array}{l}\text { A case study of eKutir platform in India identifies the following elements of the ecosystem: communities, } \\
\text { intermediaries, technology, institutions and partners. Different elements are involved throughout the development } \\
\text { process of the ecosystem. }\end{array}$ \\
\hline$[71]$ & $\begin{array}{l}\text { A case study of Volvo's connected car initiative suggests that to embrace digital innovation, incumbent firms must } \\
\text { develop new capabilities. Digital innovation has generative capacity - the process of innovation must be the key focus. } \\
\text { External collaboration is essential in digital innovation. Governance mechanisms are essential for digital innovation. } \\
\text { Successful project completion requires management of episodic conflict. There is path dependency in sequential } \\
\text { conflict resolution. }\end{array}$ \\
\hline$[81]$ & $\begin{array}{l}\text { Four case studies across insurance, banking, telecom, and e-commerce industries through the service-dominant lens } \\
\text { show that big data analytics services enable sourcing, storage, event recognition and prediction, behavior recognition } \\
\text { and prediction, rule-based actions and visualizations to support service automation and analytics-enabled services. }\end{array}$ \\
\hline$[28]$ & $\begin{array}{l}\text { The authors propose a novel theoretical perspective to address the growing development of IT-enabled services,. The } \\
\text { key tenets of the perspective which the authors term "service dominant logic" are that 1) innovation is a collaborative } \\
\text { process, 2) service development requires specialized capabilities and 3) IT-enabled services lead to resource } \\
\text { liquefication that underpins the generative nature of IT-enabled service innovations. The authors also argue that service } \\
\text { innovation typically occurs within ecosystems (actor networks) and it often takes shape of service platforms. } \\
\text { Technology is both an operant and operand resource in value co-creation. }\end{array}$ \\
\hline
\end{tabular}

\subsection{The effects of IT on innovation}

Focusing on the effects of IT on innovation within organizations we find that investments in IT have a positive effect on the organizational operational capabilities and improve the probability of firm survival [46]. Investments in IT affect the competitive options available to a firm [46]. IT investments that contribute to the improvisational capabilities of a firm can be particularly beneficial in hyperturbulent environments [52, 55].

An analysis of manufacturing firms showed that a $10 \%$ increase in IT spending was associated with a $1.7 \%$ increase in sales in the period between 19871997. However, later studies found diminishing returns to IT investments, particularly in the nontechnology sectors of the economy [65]. In the technology sector, investments in IT can help mitigate diminishing returns from $R \& D$ investments [59].

Research focusing on the interplay between different types of investments found that IT investments had a substitutive effect on labor investments, whereas IT investments were complementary to financial capital investments [20]. More recent studies focusing on the IT-enabled analytical capabilities have found that ownership of big data assets was associated with 3-7\% improvement in the firms' productivity [30], and analytical processing capabilities have a positive relationship with the number of patents [64].

Several studies have also documented potential negative effects of IT. Technology-driven innovations can produce disruptions undermining value chains of existing businesses and leading to hyperturbulence within industries [52]. A study of IT investments by Fortune 1000 firms has also documented that a greater investment in IT was associated with higher stock price volatility implying greater investment risk [25].

\subsection{Moderators of IT effects on innovation}

A number of studies have examined both organizational as well as environmental variables as moderators of the effects of investments in IT assets and IT-enabled capabilities. Focusing on the organizational factors, Joshi et al. [43] showed that potential IT-enabled absorptive capacity is not always realized and this can undermine firm performance. The firm size is an important factor in the value generated from IT investments - larger firms tend to realize greater benefits [72]. Susarla and Barua [70] showed that contractual misalignment with the underlying cost structure can prevent a business from realizing value from IT investments. Focusing on the environmental factors that affect value of IT investments, we find that IT-intensity and level of competition within an industry have a positive effect on the return from IT investments [30].

\subsection{Native IS theories}

In our sample, we find two manuscripts that develop novel IS theories. Ning and Tanriverdi [52] address the question of how IT-enabled capabilities affect firm response to environmental hyperturbulence. Through agent-based modeling, the authors argue that while external IT-driven innovations can be a source of environmental hyperturbulence, internal IT-enabled capabilities can support an effective firm response through IT-enabled innovation.

The Lusch and Nambisan manuscript on service dominant logic [28] is the second theoretical manuscript in our sample. The authors argue that ITenabled services require a novel theoretical perspective to understand the factors that underpin service innovation. The authors propose that a service- 
dominant logic that emphasizes the collaborative nature of innovation, the strategic value of specialized competencies within the value networks, and the generativity of digital innovations affords an opportunity to gain richer insight. Importantly, within this framework IT is both an operand and operant resource, i.e. IT is both a resource for service delivery and the product of the innovation effort.

\section{Discussion}

\subsection{Dominant theories and their limitations}

In our analysis of the dominant theories in our sample, we find that the resource-based view and the dynamic capabilities theories are the most cited theoretical frameworks. RBV argues that rare, valuable, hard to imitate and to substitute resources offer a competitive advantage to the firms that possess them $[8,10]$. Dynamic capabilities theory builds on $\mathrm{RBV}$ and it posits that it is not just the resources, but rather what organizations do with the resources that gives firms an advantage [27].

The appeal of both RBV and dynamic capabilities is that it is relatively easy to instrument both the predictors and the dependent variables in the empirical assessments of the frameworks. Despite their appeal, both RBV and dynamic capabilities theories have significant weaknesses. RBV has a problem with potential tautology of the argument [57]. The valuable aspect of the resource evaluation requires the benefit of hindsight to know which resources would prove valuable in the context of continually evolving industries. The value of resources is hard to assess before disruptions occur. For example, Polaroid and Kodak held many valuable resources (technology, patents, brand recognition, marketing channels, etc.), yet the companies were unable to realize the asset value potential with the emergence of the digital cameras, which in turn have largely lost the market to smart phone manufacturers $[47,76]$.

The dynamic capabilities theory inherits the weakness of the RBV argument. Capabilities are typically instrumented as managerial perceptions of organizational competencies. It is difficult to know which capabilities would prove advantageous without knowing the next step in the evolution of specific markets and industries. One might expect that the innovation capability, i.e. the ability of a firm to develop technical innovations, would be highly advantageous in this domain, yet we find cases of companies that had spectacularly failed to commercialize their innovations. Xerox PARC developed many of the core innovations in modern computing, e.g. the graphical user interface, laser printing, and Ethernet network technologies, yet the company largely failed to monetize these innovations [17]. More recently, Yahoo was an early leader in the big data analytics domain, yet the company generally failed to monetize its capabilities, and Yahoo's technical innovations and talent were absorbed by other firms [66].

\subsection{Novel frameworks and opportunities for future research}

While we found only two novel theoretical frameworks among the studies in our review, both address important emergent topics. Ning and Tanriverdi [52] examine the role of IT-enabled capabilities in a firm's response to disruptive innovations and suggest that IT-enabled capabilities are a critical component of a successful response. The service dominant logic articulated by Lusch and Nambisan [28] draws attention to IT-enabled services which represent a growing sector of the economy [14]. The proposed framework highlights the distributed nature of value creation and the key role of IT-enabled services in supporting flexibility in continuous rearchitecting of business value creation and delivery [14]. The two theoretical frameworks address the key modern business challenges: transition to IT-enabled service delivery across many industries with the consummate revision of value delivery that often involves industry disruptions.

While it is clear that IT will play a central role in creating the disruptions, there are ample opportunities to develop more cohesive perspectives on the key factors and practices that affect business performance and competitive position. We have found limited integration of known organizational factors within the studies in our sample. Integration of research across management and information systems literatures will likely yield key insights on the interplay between individual, social and organizational factors with IT in developing a sustainable advantage through innovation.

\section{Conclusion}

This study is a step in a broader effort to integrate insights from research on the role of information systems in innovation. This review examined studies published in the past ten years in the top four Information Systems journals focusing on the organizational level of analysis. We found that while a relatively narrow theoretical base supports much of the published research and there is limited integration of known organizational factors, e.g. leadership, in the studies of IT effects on innovation, novel theoretical 
perspectives recognize the dual role of IT both as a source of environmental turbulence and as a critical element of competitive response. The servicedominant logic also promises to serve as a fertile foundation for research on the role of IT in the growing service economy.

\section{References}

[1] Amabile, T., Componential theory of creativity, Harvard Business School, 2011.

[2] Amabile, T., and S. Kramer, The progress principle: Using small wins to ignite joy, engagement, and creativity at work, Harvard Business Press, 2011.

[3] Anderson, N., C.K.W. De Dreu, and B.A. Nijstad, "The routinization of innovation research: A constructively critical review of the state-of-the-science", Journal of Organizational Behavior 25(2), 2004, pp. 147-173.

[4] Anderson, N., K. Potočnik, and J. Zhou, "Innovation and Creativity in Organizations: A State-of-the-Science Review, Prospective Commentary, and Guiding Framework", Journal of Management 40(5), 2014, pp. 1297-1333

[5] Anderson, N.R., and M.A. West, "Measuring climate for work group innovation: development and validation of the team climate inventory", Journal of Organizational Behavior: The International Journal of Industrial, Occupational and Organizational Psychology and Behavior 19(3), 1998, pp. 235-258.

[6] Bala, H., A.P. Massey, and M.M. Montoya, "The Effects of Process Orientations on Collaboration Technology Use and Outcomes in Product Development", Journal of Management Information Systems 34(2), 2017, pp. 520-559.

[7] Bardhan, I., V. Krishnan, and S. Lin, "Research NoteBusiness Value of Information Technology: Testing the Interaction Effect of IT and R\&D on Tobin's Q", Information Systems Research 24(4), 2013, pp. 1147-1161.

[8] Barney, J., "Information Technology and Sustained Competitive Advantage: A Analysis IT and Competitive Advantage", MIS Quarterly 19(4), 1995, pp. 487-505.

[9] Barney, J.B., "Resource-based theories of competitive advantage: A ten-year retrospective on the resource-based view", Journal of Managementanagement 27(6), 2001, pp. 643-650.

[10] Barney, J.B., D.J. Ketchen, and M. Wright, "The future of resource-based theory: Revitalization or decline?", Journal of Management 37(5), 2011, pp. 1299 1315.

[11] Barua, A., and D. Mani, "Reexamining the market value of information technology events", Information Systems Research 29(1), 2018, pp. 225-240.

[12] Bayus, B., "Crowdsourcing new product ideas over time: An analysis of the Dell IdeaStorm community", Management Science 51(1), 2013, pp. 226-244.
[13] Bessant, J., R. Kaplinsky, and R. Lamming, "Putting supply chain learning into practice", International Journal of Operations \& Production Management 23(2), 2003, pp. 167-184.

[14] Buera, F.J., and J.P. Kaboski, "The rise of the service economy", American Economic Review 102(6), 2012, pp. 2540-2569.

[15] Chatterjee, S., G. Moody, P.B. Lowry, S. Chakraborty, and A. Hardin, "Strategic Relevance of Organizational Virtues Enabled by Information Technology in Organizational Innovation", Journal of Management Information Systems 32(3), 2015, pp. 158-196.

[16] Chen, D.Q., D.S. Preston, and M. Swink, "How the Use of Big Data Analytics Affects Value Creation in Supply Chain Management", Journal of Management Information Systems 32(4), 2015, pp. 4-39.

[17] Chesbrough, H., "Graceful exits and missed opportunities: Xerox's management of its technology spinoff organizations", Business History Review 76(4), 2002, pp. $803-837$.

[18] Chesbrough, H., "The era of open innovation", Managing innovation and change 127(3), 2006, pp. 34-41.

[19] Chiesa, V., P. Coughlan, and C.A. Voss, "Development of a technical innovation audit", Journal of Product Innovation Management: an international publication of the product development \& management association 13(2), 1996, pp. 105-136.

[20] Chwelos, P., R. Ramirez, K.L. Kraemer, and N.P. Melville, "Research Note-Does Technological Progress Alter the Nature of Information Technology as a Production Input? New Evidence and New Results", Information Systems Research 21(2), 2009, pp. 392-408.

[21] Crossan, M., and J. Hulland, "Leveraging knowledge through leadership of organizational learning", Strategic management of intellectual capital and organizational knowledge: A collection of readings, 2002, pp. 711-723.

[22] Crossan, M.M., and M. Apaydin, "A multidimensional framework of organizational innovation: A systematic review of the literature", Journal of Management Studies 47(6), 2010, pp. 1154-1191.

[23] Damanpour, F., "Organizational innovation: A metaanalysis of effects of determinants and moderators", Academy of Management Journal 34(3), 1991, pp. 555590.

[24] Davenport, T.H., Process innovation: reengineering work through information technology, Harvard Business Press, 1993.

[25] Dewan, S., and F. Ren, "Information Technology and Firm Boundaries: Impact on Firm Risk and Return Performance", Information Systems Research 22(2), 2009, pp. 369-388.

[26] Dewar, R.D., and J.E. Dutton, "The adoption of radical and incremental innovations: An empirical analysis", Management science 32(11), 1986, pp. 1422-1433. 
[27] Eisenhardt, K.M., and J.A. Martin, "Dynamic capabilities: what are they?", Strategic Management Journal 21(10-11), 2000, pp. 1105-1121.

[28] Erspective, L.O.P., and R.F. Lusch, "Service Innovation: A Service-Dominant-Logic perspective", $M I S$ Quarterly 39(1), 2015, pp. 155-175.

[29] Ettlie, J.E., W.P. Bridges, and R.D. O'keefe, "Organization strategy and structural differences for radical versus incremental innovation", Management Science 30(6), 1984, pp. 682-695.

[30] Fay, M., O. Muller, and J. vom Brocke, "The effect of big data and analytics on firm performance: An econometric analysis considering industry characteristics", Journal of Management Information Systems 35(March), 2018, pp. 488-509.

[31] Felin, T., and T.R. Zenger, "Closed or open innovation? Problem solving and the governance choice", Research Policy 43(5), 2014, pp. 914-925.

[32] Fichman, R.G., and N.P. Melville, "How PostureProfile Misalignment in IT Innovation Diminishes Returns: Conceptual Development and Empirical Demonstration", Journal of Management Information Systems 31(1), 2014, pp. 203-240.

[33] Garcia, R., and R. Calantone, "A critical look at technological innovation typology and innovativeness: a literature review", The Journal of Product Innovation Management 19(2), 2002, pp. 110-132.

[34] Gassmann, O., E. Enkel, and H. Chesbrough, "The future of open innovation”, $R \& D$ Management 40(3), 2010, pp. 213-221.

[35] Goodstein, J., K. Gautam, and W. Boeker, "The effects of board size and diversity on strategic change", Strategic Management Journal 15(3), 1994, pp. 241-250.

[36] Havakhor, T., R. Sabherwal, Z.R. Steelman, and S. Sabherwal, "Relationships between information technology and other investments: A contingent interaction model", Information Systems Research, 2019.

[37] Henfridsson, O., and B. Bygstad, "The Generative Mechanisms of Digital Infrastructure Evolution", MIS Quarterly 37(3), 2013, pp. 907-931.

[38] Hill, C.W.L., and F.T. Rothaermel, "The performance of incumbent firms in the face of radical technological innovation", Academy of Management Review 28(2), 2003, pp. 257-274.

[39] Hitt, L.M., and P. Tambe, "The productivity of information technology investments: New Evidence from IT Labor Data", Information Systems Research(April 2019), 2012.

[40] Huang, J., O. Henfridsson, M.J. Liu, and S. Newell, "Growing on Steroids: Rapidly Scaling the User Base of Digital Ventures Through Digital Innovation", MIS Quarterly 41(1), 2017, pp. 301-314.

[41] Jha, S.K., A. Pinsonneault, and L. Dubé, “The evolution of an ict platform-enabled ecosystem for poverty alleviation”, MIS Quarterly 40(2), 2016, pp. 431-446.

[42] Joshi, K.D., L. Chi, A. Datta, and S. Han, "Changing the competitive landscape: Continuous innovation through IT-enabled knowledge capabilities", Information Systems Research 21(3), 2010, pp. 472-495.

[43] Joshi, K.D., L. Chi, A. Datta, and S. Han, "Changing the competitive landscape: Continuous innovation through IT-enabled knowledge capabilities", Information Systems Research 21(3), 2010, pp. 472-495.

[44] Kleis, L., Paul Chwelos, Ronald V. Ramirez, and Iain Cockburn, "Impact of IT Investment on Innovation Productivity Information Technology and Intangible Output", Information Systems Research 23(1), 2012, pp. 42-59.

[45] Lewin, A.Y., S. Massini, and C. Peeters, "Microfoundations of internal and external absorptive capacity routines", Organization Science 22(1), 2011, pp. 81-98.

[46] Li, S., J. Shang, and S.A. Slaughter, "Why Do Software Firms Fail? Capabilities, Competitive Actions, and Firm Survival in the Software Industry from 1995 to 2007”, Information Systems Research 21(3), 2010, pp. 631-654.

[47] Lucas Jr, H.C., and J.M. Goh, "Disruptive technology: How Kodak missed the digital photography revolution", The Journal of Strategic Information Systems 18(1), 2009, pp. 46-55.

[48] Lusch, R.F., and S. Nambisan, "Service Innovation: A Service-Dominant-Logic perspective.”, MIS Quarterly 39(1), 2015, pp. 155-176.

[49] Mamonov, S., and R. Peterson, "IT Impact on Innovation at the Individual and Group Level-A Literature Review", Proceedings of the 52nd Hawaii International Conference on System Sciences, (2019).

[50] McLean, L.D., “Organizational culture's influence on creativity and innovation: A review of the literature and implications for human resource development", Advances in developing human resources 7(2), 2005, pp. 226-246.

[51] Nambisan, S., K. Lyytinen, A. Majchrzak, and M. Song, "Information technology and innovation", MIS Quartely, 2014.

[52] Ning, N., and H. Tanriverdi, "Unifying the role of it in hyperturbulence and competitive advantage via a multilevel perspective of is strategy", MIS Quarterly 41(3), 2017, pp. 937-A8.

[53] Norman, D.A., and R. Verganti, "Incremental and radical innovation: Design research vs. technology and meaning change", Design issues 30(1), 2014, pp. 78-96.

[54] Pavlou, P.A., and O.A. El Sawy, "The 'Third Hand': IT-Enabled Competitive Advantage in Turbulence Through Improvisational Capabilities", Information Systems Research 21(3), 2010, pp. 443-471.

[55] Pavlou, P.A., and O.A.E. Sawy, “The 'third hand': ITenabled competitive advantage in turbulence through 
improvisational capabilities", Information Systems Research 21(3), 2010, pp. 443-471.

[56] Ping, S., -Ju Wu, D.W. Straub, and T.-P. Liang, "How Information Technology Governance Mechanisms and Strategic Alignment Influence Organizational Performance: Insights From a Matched Survey of Business and It Managers 1", MIS Quarterly 39(2), 2015, pp. 497-518.

[57] Priem, R.L., and J.E. Butler, "Tautology in the resource-based view and the implications of externally determined resource value: Further comments", Academy of Management review 26(1), 2001, pp. 57-66.

[58] Priem, R.L., S. Li, and J.C. Carr, "Insights and new directions from demand-side approaches to technology innovation, entrepreneurship, and strategic management research", Journal of Management 38(1), 2012, pp. 346374.

[59] Ravichandran, T., S. Han, and S. Mithas, "Information Systems Research Mitigating Diminishing Returns to R\&D: The Role of Information Technology in Innovation", Information Systems Research 28(4), 2017, pp. 812-827.

[60] Read, A., "Determinants of successful organisational innovation: a review of current research", Journal of Management Practice 3(1), 2000, pp. 95-119.

[61] Roberts, N., D.E. Campbell, and L.R. Vijayasarathy, "Using Information Systems to Sense Opportunities for Innovation: Integrating Postadoptive Use Behaviors with the Dynamic Managerial Capability Perspective", Journal of Management Information Systems 33(1), 2016, 45-69.

[62] Roberts, N., and V. Grover, "Leveraging Information Technology Infrastructure to Facilitate a Firm's Customer Agility and Competitive Activity: An Empirical Investigation", Journal of Management Information Systems 28(4), 2012, pp. 231-270.

[63] Saldanha, T.J. V., S. Mithas, and M.S. Krishnan, "Leveraging Customer Involvement for Fueling Innovation: The Role of Relational and Analytical Information Processing Capabilities", MIS Quarterly 41(1), 2017, pp. 367-396.

[64] Saldanha, T.J. V, S. Mithas, and M.S. Krishnan, "Leveraging Customer Involvement for Fueling Innovation: The Role of Relational and Analytical Information Processing Capabilities", MIS Quarterly 41(1), 2017, pp. 367-396.

[65] Dos Santos, B.L., Z. Zheng, V.S. Mookerjee, and H. Chen, "Are new IT-enabled investment opportunities diminishing for firms?", Information Systems Research 23(2), 2012, pp. 287-305.

[66] Schmarzo, B., Big Data: Understanding how data powers big business, John Wiley \& Sons, 2013.

[67] Singh, R., L. Mathiassen, and A. Mishra, "Organizational Path Constitution in Technological Innovation: Evidence from Rural Telehealth", MIS Quarterly 39(3), 2015, pp. 643-666.

[68] Steelman, Z.R., T. Havakhor, R. Sabherwal, and S. Sabherwal, "Performance consequences of information technology investments: Implications of emphasizing new or current information technologies", Information Systems Research, 2019.

[69] Straub, D.W., "Why Top Journals Accept Your Paper.”, MIS Quarterly 33(3), 2009, pp. iii-X.

[70] Susarla, A., and A. Barua, "Contracting efficiency and new firm survival in markets enabled by information technology", Information Systems Research 22(2), 2011, pp. 306-324.

[71] Svahn, F., L. Mathiassen, and R. Lindgren, "Embracing Digital Innovation in Incumbent Firms: How Volvo Cars Managed Competing Concerns", MIS Quarterly 41(1), 2017, pp. 239-253.

[72] Tambe, P., and L.M. Hitt, "The Productivity of Information Technology Investments: New Evidence from IT Labor Data", Information Systems Research 23(3-part1), 2012, pp. 599-617.

[73] Teece, D.J., G. Pisano, and A. Shuen, "Dynamic capabilities and strategic management", Strategic Management Journal 18(7), 1997, pp. 509-533.

[74] Tipping, J.W., E. Zeffren, and A.R. Fusfeld, "Assessing the value of your technology", ResearchTechnology Management 38(5), 1995, pp. 22-39.

[75] Trantopoulos, K., G. von Krogh, M.W. Wallin, and M. Woerter, "External Knowledge and Information Technology: Implications for Process Innovation Performance", MIS Quarterly 41(1), 2017, pp. 287-300.

[76] Tripsas, M., and G. Gavetti, "Capabilities, cognition, and inertia: Evidence from digital imaging", Strategic management journal 21(10-11), 2000, pp. 1147-1161.

[77] Vannoy, S.A., and A.F. Salam, "Managerial Interpretations of the Role of Information Systems in Competitive Actions and Firm Performance: A Grounded Theory Investigation", Information Systems Research 21(3), 2010, pp. 496-515.

[78] Verhaeghe, A., and R. Kfir, "Managing innovation in a knowledge intensive technology organisation (KITO)", $R \& D$ Management 32(5), 2002, pp. 409-417.

[79] Wang, P., "Chasing the hottest it: effects of information technology fashion on organizations.", MIS Quarterly 34(1), 2010, pp. 63-85.

[80] Webster, J., and R.T. Watson, "Analyzing the past to prepare for the future: Writing a literature review", $M I S$ Quarterly, 2002, pp. xiii-xxiii.

[81] Wieneke, A., J. vom Brocke, C. Lehrer, S. Seidel, and R. Jung, "How Big Data Analytics Enables Service Innovation: Materiality, Affordance, and the Individualization of Service", Journal of Management Information Systems 35(2), 2018, pp. 424-460.

[82] Xue, L., G. Ray, and V. Sambamurthy, "Efficiency or innovation: how do industry environments moderate the effects of firms' it asset portfolios?", MIS Quarterly 36(2), 2012, pp. 509-528. 